\title{
Self-Fluxing Agglomerates in the USSR
}

\author{
Based on an article \\ submitted by the Soviet Delegation to the Steel Committee of the United Nations' \\ Economic Commission for Europe, appearing in Advances in Steel Technology in \\ 1955, published by the United Nations, Geneva, Switzerland, 1956.
}

$\mathbf{I}^{\mathrm{N}}$ Russia, two steel plants are operating blast furnaces on burdens containing from 75 to 90 pct agglomerates. In order to improve the operation it was decided to add flux, in the form of finely ground limestone, to the agglomerate. In this manner, the decomposition of the limestone does not take place in the blast furnace but rather on the agglomeration strand, thereby substantially reducing the blast furnace coke rate and increasing output.

At plant $\mathrm{A}$, the limestone is received in a size range of $10 \mathrm{~mm}$ to $100 \mathrm{~mm}$, ground in a hammer mill, and screened in a closed circuit to $-4 \mathrm{~mm}$. At plant B, a ball mill is employed for dry grinding the limestone to between 85 and 90 pct $-3 \mathrm{~mm}$.

At plant $\mathrm{A}$, between 16 and 18 pct limestone is added to the agglomeration mixture to produce an agglomerate with average basicity $\left(\mathrm{CaO}: \mathrm{SiO}_{2}\right)$ of 1.3. During agglomeration, intimate contact is established between the limestone and other constituents, resulting in an agglomerate of satisfactory mechanical strength. The elimination of sulfur is not decreased by limestone additions. Moreover, the introduction of limestone renders the agglomerate more reducible in the blast furnace, for such lime agglomerate contains less iron chemically combined with silica.

Table I shows the composition of lime and nonlime agglomerates at plant A, while Table II has data on agglomeration mixes at plant B. It should be noted that increasing the quantity of limestone in plant B resulted in considerably increased production rates on the agglomeration bed.

Table III shows the blast furnace operation resulting from varying quantities of lime agglomerate in the burden at plant $\mathrm{A}$. With increasing quantities the coke rate decreases and output increases constantly over that obtained with ordinary agglomerate in the charge. With basicity of 1.26 and using 86.4 pct lime agglomerate in the burden, the coke rate is 11.1 pct less and the output 12.2 pct more than when charging with ordinary agglomerate. In spite of increasing quantities of $\mathrm{CaO}$ instead of $\mathrm{CaCO}_{3}$ in the

Table I. Composition of Lime and Nonlime Agglomerates at Plant A

\begin{tabular}{|c|c|c|c|c|c|c|c|c|}
\hline \multirow{2}{*}{$\begin{array}{c}\text { Agglomerate } \\
\text { Type }\end{array}$} & \multicolumn{8}{|c|}{ Composition, Pet } \\
\hline & $\mathbf{F e}$ & FeO & $\mathbf{S i O}_{2} *$ & $\mathrm{CaO}$ & MgO & $\mathbf{A l}_{2} \mathbf{O}_{3}$ & $\mathbf{s}$ & $\mathbf{S i O}_{2} *$ \\
\hline \multirow{4}{*}{$\begin{array}{l}\text { High } S \text { magnetite } \\
\text { concentrate, lime- } \\
\text { stone added } \\
\text { High } S \text { magnetite } \\
\text { concentrate, no } \\
\text { limestone } \\
\text { High } S \text { oxide fines, } \\
\text { concentrate, lime- } \\
\text { stone added } \\
\text { High } S \text { oxide fines, } \\
\text { concentrate, no } \\
\text { limestone }\end{array}$} & 55.2 & 16.4 & 7.81 & 10.33 & 1.86 & 2.52 & 0.040 & 1.32 \\
\hline & 61.2 & 23.6 & 8.45 & 2.10 & 0.65 & 2.55 & 0.036 & 0.25 \\
\hline & 52.2 & 17.0 & 9.34 & 12.55 & 1.24 & 3.60 & 0.043 & 1.34 \\
\hline & 58.3 & 23.2 & 10.32 & 2.96 & 0.6 & 4.49 & 0.027 & 0.29 \\
\hline
\end{tabular}

burden, the $\mathrm{CO}_{2}$ at the furnace throat shows a slight increase with higher lime agglomerate burdens, indicating increasing indirect reduction of ore by furnace gases.

Table IV shows the results obtained from operating with ordinary and with lime agglomerates at plant B. By using some 63 pct lime agglomerate of 0.6 basicity, coke rates were reduced by about 6 pct as compared with ordinary agglomerate burden operation, and at the same time output was increased by as much as 5.3 pct.

The experimental burdening of blast furnaces at these two plants shows that the use of lime agglomerate results in a reduction of coke rates and an increase in the rate of blast furnace output.

Table II. Agglomeration Characteristics of Lime and Nonlime Agglomeration Mixes at Plant B

\begin{tabular}{|c|c|c|}
\hline & $\underset{\text { Ogglomerate }}{\text { Ordinary }}$ & $\underset{\text { Agglomerate }}{\text { Lime }}$ \\
\hline $\begin{aligned} \text { Basicity }\left(\mathrm{CaO}: \mathrm{SiO}_{2}\right) \\
\text { Analysis in pct: } \\
\mathrm{Fe} \\
\mathrm{FeO} \\
\mathrm{CaO}\end{aligned}$ & $\begin{array}{r}0.12 \\
61.0 \\
21.2 \\
1.4\end{array}$ & $\begin{array}{r}0.6 \\
57.5 \\
11.6 \\
6.5\end{array}$ \\
\hline $\begin{array}{l}\text { Size analysis at mixers } \\
>25 \mathrm{~mm} \\
25 \text { to } 12 \mathrm{~mm} \\
12 \text { to } 5 \mathrm{~mm} \\
<5 \mathrm{~mm}\end{array}$ & $\begin{array}{l}29.8 \\
23.7 \\
23.6 \\
22.9\end{array}$ & $\begin{array}{l}27.6 \\
17.7 \\
27.7 \\
27.0\end{array}$ \\
\hline $\begin{array}{l}\text { Production of agglomeration } \\
\text { band, tons per } \mathrm{hr}\end{array}$ & 70.0 & 80.3 \\
\hline
\end{tabular}

Table III. Blast Furnace Operation at Plant A with Normal and Lime Agglomerates

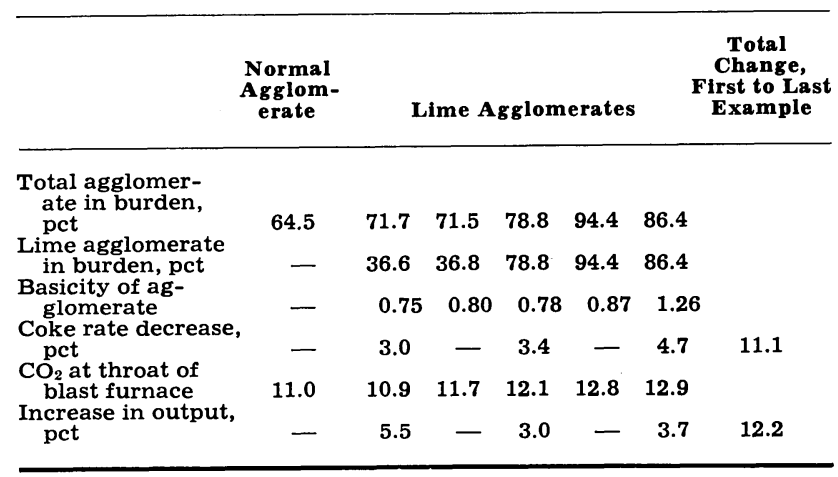

Table IV. Operating Results of Blast Furnaces One and Two, Plant B, with Normal and Lime Agglomerates

\begin{tabular}{|c|c|c|c|c|}
\hline \multirow{5}{*}{$\begin{array}{l}\text { Total agglomerate in burden, } \\
\text { pct } \\
\text { Lime agglomerate in burden, } \\
\text { pct } \\
\text { Fe in burden, pct } \\
\text { Coke rate, kg per ton iron } \\
\text { Dust at furnace throat, } \\
\text { kg per ton iron }\end{array}$} & \multicolumn{2}{|c|}{$\begin{array}{c}\text { Blast } \\
\text { Furnace One }\end{array}$} & \multicolumn{2}{|c|}{$\begin{array}{c}\text { Blast } \\
\text { Furnace Two }\end{array}$} \\
\hline & 75.7 & 74.1 & 78.6 & 72.0 \\
\hline & - & 64.4 & & \\
\hline & $\begin{array}{r}44.2 \\
867\end{array}$ & $\begin{array}{l}44.5 \\
815\end{array}$ & $\begin{array}{l}44.1 \\
864\end{array}$ & 814 \\
\hline & 211 & 152 & 129 & 81 \\
\hline
\end{tabular}

